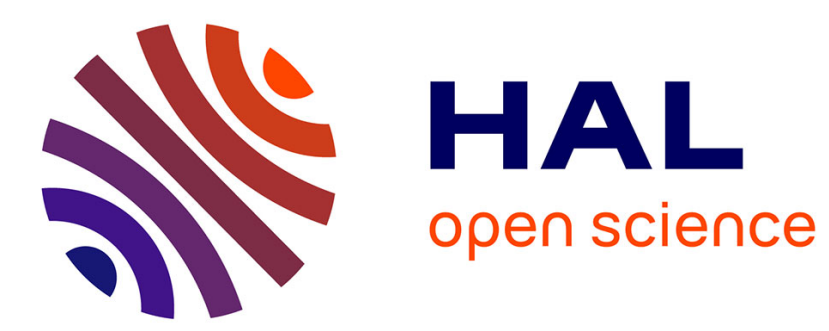

\title{
CHANGES OF THE ACTIVITY OF CERTAIN ENZYMES IN HUMAN SERUM UNDER THE INFLUENCE OF ARGON LASER RADIATION
}

L. Wolf, A. Drobnik, M. Sopi ski

\section{- To cite this version:}

L. Wolf, A. Drobnik, M. Sopi ski. CHANGES OF THE ACTIVITY OF CERTAIN ENZYMES IN HUMAN SERUM UNDER THE INFLUENCE OF ARGON LASER RADIATION. Journal de Physique IV Proceedings, 1991, 01 (C7), pp.C7-267-C7-267. 10.1051/jp4:1991772 . jpa-00251015

\section{HAL Id: jpa-00251015 https://hal.science/jpa-00251015}

Submitted on 1 Jan 1991

HAL is a multi-disciplinary open access archive for the deposit and dissemination of scientific research documents, whether they are published or not. The documents may come from teaching and research institutions in France or abroad, or from public or private research centers.
L'archive ouverte pluridisciplinaire HAL, est destinée au dépôt et à la diffusion de documents scientifiques de niveau recherche, publiés ou non, émanant des établissements d'enseignement et de recherche français ou étrangers, des laboratoires publics ou privés. 


\section{CHANGES OF THE ACTIVITY OF CERTAIN ENZYMES IN HUMAN SERUM UNDER THE INFLUENCE OF ARGON LASER RADIATION}

L. WOLF, A. DROBNIK and M. SOPIN'SKI*

Technical University of Lódź, Institute of Physics, Wblczanska 219, PL-93-005 Lбdż, Poland * Department of Histology and Embriology Medical Academy of Lódż, Narutowicza 60, PL-90-136 LGdż, Poland

The autors conduct the investigations on the blanching of port wine stains (PWS) with the aid of argon laser radiation. In the examination of blood of the patients subjected to this treatment the activity of the following enzymes was determinated :

E.L.2.6.1.1 L - asparaginian :2-oksyglutaran aminotranspherase

E.L.2.6.1.2 L - alamina : 2 - oksyglutaran aminotranspherase and

E.L.2.7.3.2.ATP creatin phosphotransferase.

The activity of this enzymes was determined with the aid optical test utilising $\mathrm{NAO}^{+}$and $\mathrm{NADH}_{2}$.

The increase of the examinated enzymes activity was observed in the blood serum of the patients immediatelly after the icradiations.

Further examinations could explain the reason of the observed phenomenon and its significance in laser therapy. 